\title{
Effect of polydextrose and stevia on quality characteristics of low-calorie biscuits
}

\author{
${ }^{1,2}$ Rana, M.S., ${ }^{1,3}$ Das, P.C., ${ }^{1,2}$ Yeasmin, F. and ${ }^{1, *}$ Islam, M.N. \\ ${ }^{1}$ Department of Food Technology and Rural Industries, Bangladesh Agricultural University, Mymensingh - \\ 2202, Bangladesh \\ ${ }^{2}$ Department of Agro Product Processing Technology, Jashore University of Science and Technology, \\ Jashore - 7408, Bangladesh \\ ${ }^{3}$ Department of Chemical and Food Process Engineering, Rajshahi University of Engineering and \\ Technology, Rajshahi - 6204, Bangladesh
}

\section{Article history:}

Received: 12 May 2020

Received in revised form: 17

June 2020

Accepted: 4 July 2020

Available Online: 7 August 2020

\section{Keywords:}

Biscuits,

Low sugar,

Low fat,

Polydextrose,

Stevia,

Physico - chemical analysis,

\section{DOI:}

https://doi.org/10.26656/fr.2017.4(6).223

\begin{abstract}
Lipid and sugar have important nutritional and technological functions in bakery products, but excessive intake may affect human health adversely. This study aimed at processing and quality evaluation of low-calorie biscuits by partial replacement of fat and sugar with polydextrose and $2.5 \%$ stevia solution, respectively. A total of 6 formulas and 16 samples of biscuit were developed to replace the amount of fat and sugar from 0 to $50 \%$. For each formula (10 to $50 \%$ fat and sugar reduction), 3 biscuit samples were prepared with different proportion of polydextrose and stevia whilst exception for control (1 sample, $0 \%$ fat and sugar reduction). Analysis on physical properties of the developed biscuits showed that the diameter, thickness, spread ratio, mass, volume, density and compressive strength were changed with the change in fat and sugar content and values were found in the range of $3.57-3.9 \mathrm{~cm}, 0.5-0.7 \mathrm{~cm}, 5.58-7.10,3.63-4.2 \mathrm{~g}, 5.03-8.34 \mathrm{cc}, 0.49-0.74 \mathrm{~g} / \mathrm{cc}$ and 9.383 - $16.441 \mathrm{kgf}$, respectively. Proximate nutritional components of the developed biscuit samples were varied significantly $(p \leq 0.05)$ due to increasing of polydextrose and stevia, and the values were recorded as $4.36-4.99 \%$ for moisture, $7.81-8.91 \%$ protein, $11.37-17.88 \%$ fat, $1.09-1.24 \%$ ash and $68.65-73.72 \%$ total carbohydrate. The usage of $5 \mathrm{~mL}$ stevia solution and $3 \mathrm{~g}$ polydextrose to reduce $50 \%$ fat and $50 \%$ sugar resulted in lowering $12.59 \%$ calorie content than control biscuit. Concerning sensory evaluation, a noticeable significant difference was found among the developed biscuits at $p \leq 0.05$, whereas all samples got acceptable scores. However, this study revealed that the replacement of fat and sugar by polydextrose and stevia up to $50 \%$ in biscuits is acceptable without too appreciable changes in physico-chemical and sensory properties.
\end{abstract}

\section{Introduction}

Nowadays, food industries are focusing on consumer health issues. Besides, people are conscious about the foods which have higher fat, cholesterol and sugar because of the possibility of being affected by different diseases including coronary heart disease, fatness, hypertension, different cancers, gall bladder diseases etc. (Ding and Malik, 2008). Excess fat and sugar consumptions have adverse effects on human health and there is a clear link between excessive dietary fat consumption and risk of cardiovascular disease (Viana et al., 2003). Researches also illustrate linkages between highly glycemic diets and various types of cancer (Eyre et al., 2004; Bonovas et al., 2004; Ding and Malik,
2008). By concerning these alarming conditions, instead of eating high fat and sugar, people are so much interested in low-calorie foods (Akoh, 1995).

Biscuits are small cakes, prepared by wheat flour, fat, sugar and other ingredients by mixing, conditioning and passing between rollers to make a sheet before being baked (Das et al., 2018). Consumer demand is changing for the quality of biscuits with taste, safety, convenience and nutrition (Masoodi and Bashir, 2012). Fats and sugar impart many functional, nutritional and sensory properties of bakery foods. Fats improve texture, mouthfeel, structure and lubricity in foods (Giese, 1996), whereas sugar provides volume, texture, color and 
sweetness (Zoulias et al., 2000).

Foods with low fat and sugar are often lack of palatability. Several natural and artificial components are generally used as fat replacers to substitute the amount of fat in food items (Aggarwal et al., 2016). Fat substitutes are food ingredients that can replace fat totally or partially with similar organoleptic properties in foods (Lim et al., 2010). Several carbohydrates, protein, or lipid - based fat replacers are being used individually or in combination (Mitchell, 1996; Akoh, 1998). Polydextrose, processed sugars, derivatives of starch, cellulose, hemicellulose, gums, etc. are generally used as carbohydrate - based fat replacer (Nonaka, 1997) helps in lowering calorie for similar weight swap $4 \mathrm{kcal} / \mathrm{g}$, instead of $9 \mathrm{kcal} / \mathrm{g}$ (Lindsay, 1996).

Stevia, leaves of Stevia rebaudiana, has been getting scientific interest to replace sugar (Michaud et al., 2002; Bell and Sears, 2003). Steviol glycosides are the active compounds of stevia and are around $150-200$ times sweeter than table sugar (Romieu et al., 2004). It is heat, pH stable and non-fermentable (Franceschi et al., 2001). As the body is unable to metabolize the glycosides of stevia, it provides no calories at all. Utilization of zerocalorie sweeteners in bakery goods may have considerable effects on tenderness, color and flavor of the final products (Mariotti and Alamprese, 2012). Artificial sweetener does not take part in Maillard reaction and caramelization resulting in lighter color in food products after cooking (Gallagher et al., 2003; Lin et al., 2010).

Few researchers tried to develop biscuits by replacing fat with different fat replacers such as maltodextrin, dairytrim, pectin etc. (Zoulias et al., 2000), and also by their combination with or without other components like corn fiber, lupine extract, guar gum etc. (Forker et al., 2012). Application of polydextrose and stevia as a source of fat replacement in biscuits is yet to be studied. However, using of polydextrose and stevia to replace fat and sugar in biscuits will be an important area to be investigated. Considering above standpoints, this research was conducted under the following objectives: (a) to prepared low-calorie biscuits by using of polydextrose and stevia as fat and sugar replacers and (b) to evaluate the physicochemical and sensory features of the developed biscuits.

\section{Materials and methods}

\subsection{Materials}

Wheat flour (Teer brand), daldah (Pusti brand), salt (ACI brand), eggs, sugar (Fresh brand), polydextrose (STA-LITE), stevia (Stevia leaves extract powder, Nature Restore), vanilla essence, powdered milk
(Diploma brand) and baking powder (Nurnobi brand) were purchased from the regional market. Chemicals of Analytical Research (AR) were used for various analyses in this study.

\subsection{Formulation and preparation of biscuits}

The biscuits were made using the process by Sarker et al. (2013) and Das et al. (2018) with slight modifications. The formulation was done by the following experimental design as given in Table 1 . Firstly, the daldah (fat) was finely mashed. Blended sugar was then added to it. Thereafter, other ingredients including egg, salt, polydextrose, stevia solution $(2.5 \%$ solution), milk powder and vanilla essence were incorporated and well blended. The flour and baking powder were then added and combined well into a smooth dough. After that, the dough was shaped into thin, $3 \mathrm{~mm}$ thick consistent layer and cut out using a 3 $\mathrm{cm}$ diameter circular biscuit cutter. The biscuits were then baked in a baking oven (Sharp Electric Oven EO 257 CT-BK) at $180^{\circ} \mathrm{C}$ for 15 mins. Finally, the produced biscuits were cooled at ambient temperature and enclosed in airtight packets.

\subsection{Nutritional analysis of developed biscuits}

Proximate nutritional parameters such as moisture, ash, protein and fat content of the developed biscuits were analyzed on the basis of the method as narrated by AOAC (2012). Carbohydrate content was calculated by allowing the subtraction techniques mentioned by Pearson (1976) as carbohydrate $=100-($ protein + fat + ash + moisture content). Amount of energy for the consumption of $100 \mathrm{~g}$ biscuits was calculated by considering the total energy given by per $g$ protein, fat and carbohydrate (Okoye, 1992). Each analysis was performed in triplicate.

\subsection{Physical analysis}

Physical parameters of biscuits were analyzed by AACC (2000) methods. Spread - ratio was determined by dividing the average diameter value by the average thickness value. Digital weighing balance was used to measure the weight $(\mathrm{g})$. Thickness $(\mathrm{cm})$ and diameter (cm) were measured by slide caliper. Volume and density were calculated using thickness, diameter and mass of the biscuits. A Stable Micro Systems Texture Analyser TAXT2i (Texture Technologies Corp, England) was used to analyze biscuit texture by following Oliveira (2013).

\subsection{Sensory analysis}

Sensory parameters like color, taste, texture and overall acceptability were evaluated by following the 
Table 1. Formulation of low-calorie biscuits

\begin{tabular}{|c|c|c|c|c|c|c|c|c|c|c|c|c|}
\hline \multirow[b]{2}{*}{ Formula } & \multirow[b]{2}{*}{$\begin{array}{c}\text { Fat and sugar reduction } \\
\text { percentage }\end{array}$} & \multirow[b]{2}{*}{$\begin{array}{l}\text { Sample } \\
\text { Code }\end{array}$} & \multicolumn{10}{|c|}{ Ingredients } \\
\hline & & & $\begin{array}{l}\text { WF } \\
(\mathrm{g})\end{array}$ & $\begin{array}{l}\text { Fat } \\
(\mathrm{g})\end{array}$ & $\begin{array}{l}\text { Sugar } \\
(\mathrm{g})\end{array}$ & $\begin{array}{l}\text { MP } \\
(\mathrm{g})\end{array}$ & $\begin{array}{l}\text { BP } \\
(\mathrm{g})\end{array}$ & $\begin{array}{l}\text { Salt } \\
(\mathrm{g})\end{array}$ & $\begin{array}{l}\text { PD } \\
(\mathrm{g})\end{array}$ & $\begin{array}{c}\mathrm{SS} \\
(\mathrm{mL})\end{array}$ & $\begin{array}{l}\text { Egg } \\
(g)\end{array}$ & $\begin{array}{c}\mathrm{VE} \\
\text { (drop) }\end{array}$ \\
\hline \multirow[t]{2}{*}{ Formula 1} & $0 \%$ Fat and Sugar Reduction & $\mathrm{P}$ & 100 & 40 & 50 & 5 & 2.5 & 1.5 & 0 & 0 & 50 & 2 \\
\hline & & A & 100 & 36 & 45 & 5 & 2.5 & 1.5 & 3 & 1 & 50 & 2 \\
\hline \multirow[t]{3}{*}{ Formula 2} & $10 \%$ Fat and Sugar Reduction & $\mathrm{B}$ & 100 & 36 & 45 & 5 & 2.5 & 1.5 & 6 & 1 & 50 & 2 \\
\hline & & $\mathrm{C}$ & 100 & 36 & 45 & 5 & 2.5 & 1.5 & 9 & 1 & 50 & 2 \\
\hline & & $\mathrm{D}$ & 100 & 32 & 40 & 5 & 2.5 & 1.5 & 3 & 2 & 50 & 2 \\
\hline \multirow[t]{3}{*}{ Formula 3} & $20 \%$ Fat and Sugar Reduction & $\mathrm{E}$ & 100 & 32 & 40 & 5 & 2.5 & 1.5 & 6 & 2 & 50 & 2 \\
\hline & & $\mathrm{F}$ & 100 & 32 & 40 & 5 & 2.5 & 1.5 & 9 & 2 & 50 & 2 \\
\hline & & $\mathrm{G}$ & 100 & 28 & 35 & 5 & 2.5 & 1.5 & 3 & 3 & 50 & 2 \\
\hline \multirow[t]{3}{*}{ Formula 4} & $30 \%$ Fat and Sugar Reduction & $\mathrm{H}$ & 100 & 28 & 35 & 5 & 2.5 & 1.5 & 6 & 3 & 50 & 2 \\
\hline & & I & 100 & 28 & 35 & 5 & 2.5 & 1.5 & 9 & 3 & 50 & 2 \\
\hline & & $\mathrm{J}$ & 100 & 24 & 30 & 5 & 2.5 & 1.5 & 3 & 4 & 50 & 2 \\
\hline \multirow[t]{3}{*}{ Formula 5} & $40 \%$ Fat and Sugar Reduction & $\mathrm{K}$ & 100 & 24 & 30 & 5 & 2.5 & 1.5 & 6 & 4 & 50 & 2 \\
\hline & & $\mathrm{L}$ & 100 & 24 & 30 & 5 & 2.5 & 1.5 & 9 & 4 & 50 & 2 \\
\hline & & M & 100 & 20 & 25 & 5 & 2.5 & 1.5 & 3 & 5 & 50 & 2 \\
\hline \multirow[t]{2}{*}{ Formula 6} & $50 \%$ Fat and Sugar Reduction & $\mathrm{N}$ & 100 & 20 & 25 & 5 & 2.5 & 1.5 & 6 & 5 & 50 & 2 \\
\hline & & $\mathrm{O}$ & 100 & 20 & 25 & 5 & 2.5 & 1.5 & 9 & 5 & 50 & 2 \\
\hline
\end{tabular}

$\mathrm{WF}=$ Wheat flour, $\mathrm{MP}=$ Milk powder, $\mathrm{BP}=$ Baking powder, $\mathrm{SS}=$ Stevia solution, $\mathrm{PD}=$ Polydextrose and $\mathrm{VE}=\mathrm{Vanilla}$ essence

method described by Ranganna (2005). A semi - trained jury of 15 panelists assessed sixteen biscuit samples containing various proportions of ingredients for their sensory attributes. The 9-point hedonic rating test (Amerine et al., 1965; Sarker et al., 2013; Begum et al., 2018; Marufa et al., 2019) was used to assess the extent of acceptance at a significance level of $5 \%(p \leq 0.05)$.

\subsection{Statistical analysis}

Single factor Analysis of Variance (ANOVA) and Fisher's Least Significant Difference (LSD) Multiple Comparison Test procedures of the Method of Statistical (MSTAT) system was conducted to find the significant variation among biscuit samples for different quality parameters by following Gomez and Gomez (1984) and Das et al. (2019).

\section{Results and discussion}

3.1 Proximate composition and energy content of the processed biscuits

\subsubsection{Moisture}

The moisture content (Table 2) of the developed biscuit samples ranged as $4.36-4.99 \%$ in wb and 4.56 $5.25 \%$ in $\mathrm{db}$. The moisture content of control biscuit $(\mathrm{P})$ was $4.69 \%(\mathrm{wb})$ and $4.92 \%(\mathrm{db})$. Moisture content was decreased slightly with the fat and sugar reduction, while the addition of polydextrose results increasing of moisture. This is happened due to higher water holding capacity of polydextrose because polymers such as CMC, xanthan gum, maltodextrin, polydextrose etc. have high water empathy and can maintain foods' moisture (Nonaka, 1997). The moisture content of sample C was the highest $(4.99 \%$ in $w b$ and $5.25 \%$ in $\mathrm{db})$ than other samples whilst the lowest moisture content was observed for sample $M(4.36 \%$ in $w b$ and $4.56 \%$ in $\mathrm{db})$. The moisture content of the developed biscuits was closely related to that reported by Grah et al. (2014) as 5.13 $7.17 \%(\mathrm{db})$, Hussein et al. (2011) as $3.80-4.62 \%(\mathrm{db})$, and Das et al. (2018) as $4.35-4.91 \%(\mathrm{wb})$ and 4.55 $5.16 \%(\mathrm{db})$. Hussain and Kaul (2018) reported comparatively lower moisture content in biscuits as 2.56 - 3.42\% (wb), whereas Radhika et al. (2019) found even higher moisture content in the range of $9.30-11.60 \%$ (wb). Aggarwal et al. (2016) studied the production of low-calorie biscuits using artificial sweeteners and milk multigrain fat substitutes and found $4.30 \%(\mathrm{wb})$ moisture for control biscuit and 4.63\% (wb) for optimized lowcalorie biscuits. The variation in the moisture content of this study with that of other authors might be due to change of recipe, baking time and temperature etc.

\subsubsection{Protein}

Different biscuits samples were analyzed for protein content and values were found in the range of 7.81 $8.91 \%$. Protein content was increased significantly $(p \leq 0.05)$ with the reduction of fat and sugar, while decreased significantly $(p \leq 0.05)$ with the addition of polydextrose and stevia since wheat flour contains higher protein content. Control biscuit has the lowest $(7.81 \%)$ protein, while sample $\mathrm{M}$ had the highest protein $(8.91 \%)$. Grah et al. (2014) recorded a protein content of 6.88 $11.45 \%$ in biscuits, whereas Kabirullah et al. (1995) reported $6.88-11.78 \%$. The lower protein content of $6.60 \%$ in biscuit was reported by Seevaratnam et al. (2012). Hence, the protein contents in the prepared 
Table 2. Proximate composition of the developed biscuits

\begin{tabular}{|c|c|c|c|c|c|c|c|}
\hline \multirow{2}{*}{ Sample } & \multicolumn{2}{|c|}{ Moisture (\%) } & \multirow{2}{*}{ Protein $(\%)$} & \multirow{2}{*}{ Fat $(\%)$} & \multirow{2}{*}{ Ash (\%) } & \multirow{2}{*}{$\begin{array}{c}\text { Carbohydrate } \\
(\%)\end{array}$} & \multirow{2}{*}{$\begin{array}{c}\text { Energy } \\
\text { (Calories) }\end{array}$} \\
\hline & $\mathrm{wb}$ & $\mathrm{db}$ & & & & & \\
\hline $\mathrm{P}$ & $4.69 \pm 0.04^{\mathrm{cd}}$ & 4.92 & $7.81 \pm 0.10^{\mathrm{h}}$ & $17.88 \pm 0.08^{\mathrm{a}}$ & $1.09 \pm 0.05^{\mathrm{c}}$ & $71.75 \pm 0.03^{\mathrm{c}}$ & $479.16^{\mathrm{a}}$ \\
\hline A & $4.65 \pm 0.04^{\mathrm{d}}$ & 4.88 & $7.97 \pm 0.11^{\mathrm{g}}$ & $16.72 \pm 0.04^{\mathrm{b}}$ & $1.13 \pm 0.04^{\mathrm{bc}}$ & $70.77 \pm 0.12^{\mathrm{h}}$ & $465.44^{\mathrm{c}}$ \\
\hline $\mathrm{B}$ & $4.94 \pm 0.05^{\mathrm{ab}}$ & 5.20 & $7.88 \pm 0.09^{\mathrm{gh}}$ & $16.68 \pm 0.05^{\mathrm{bc}}$ & $1.117 \pm 0.04^{\mathrm{c}}$ & $73.72 \pm 0.08^{\mathrm{a}}$ & $476.52^{\mathrm{ab}}$ \\
\hline $\mathrm{C}$ & $4.99 \pm 0.06^{\mathrm{a}}$ & 5.25 & $7.82 \pm 0.06^{\mathrm{h}}$ & $16.65 \pm 0.05^{b c}$ & $1.09 \pm 0.05^{\mathrm{c}}$ & $73.42 \pm 0.16^{\mathrm{b}}$ & $474.81^{\mathrm{b}}$ \\
\hline $\mathrm{D}$ & $4.58 \pm 0.04^{\mathrm{de}}$ & 4.80 & $8.19 \pm 0.07^{\mathrm{ef}}$ & $15.38 \pm 0.07^{\mathrm{c}}$ & $1.14 \pm 0.03^{b c}$ & $68.65 \pm 0.13^{\mathrm{m}}$ & $445.78^{\mathrm{f}}$ \\
\hline $\mathrm{E}$ & $4.91 \pm 0.05^{\mathrm{ab}}$ & 5.16 & $8.12 \pm 0.05^{\mathrm{f}}$ & $15.35 \pm 0.06^{\mathrm{cd}}$ & $1.11 \pm 0.04^{\mathrm{c}}$ & $72.57 \pm 0.13^{\mathrm{d}}$ & $460.91^{\mathrm{d}}$ \\
\hline $\mathrm{F}$ & $4.94 \pm 0.05^{\mathrm{ab}}$ & 5.20 & $8.04 \pm 0.07^{\mathrm{fg}}$ & $15.32 \pm 0.04^{\mathrm{cd}}$ & $1.10 \pm 0.02^{\mathrm{c}}$ & $73.59 \pm 0.04^{\mathrm{ab}}$ & $464.40^{c}$ \\
\hline G & $4.48 \pm 0.05^{\mathrm{e}}$ & 4.69 & $8.45 \pm 0.07^{\mathrm{d}}$ & $14.07 \pm 0.08^{\mathrm{d}}$ & $1.18 \pm 0.04^{\mathrm{bc}}$ & $69.86 \pm 0.07^{\mathrm{k}}$ & $439.87^{\mathrm{g}}$ \\
\hline $\mathrm{H}$ & $4.86 \pm 0.06^{\mathrm{bc}}$ & 5.11 & $8.35 \pm 0.06^{\mathrm{de}}$ & $14.05 \pm 0.05^{\mathrm{de}}$ & $1.163 \pm 0.04^{\mathrm{bc}}$ & $72.75 \pm 0.02^{\mathrm{c}}$ & $450.85^{\mathrm{e}}$ \\
\hline I & $4.94 \pm 0.04^{\mathrm{ab}}$ & 5.20 & $8.27 \pm 0.09^{\mathrm{e}}$ & $14.01 \pm 0.06^{\mathrm{de}}$ & $1.152 \pm 0.04^{\mathrm{bc}}$ & $72.44 \pm 0.06^{\mathrm{de}}$ & $448.93^{\mathrm{e}}$ \\
\hline $\mathrm{J}$ & $4.41 \pm 0.05^{\mathrm{ef}}$ & 4.61 & $8.67 \pm 0.06^{b c}$ & $12.75 \pm 0.05^{\mathrm{e}}$ & $1.197 \pm 0.02^{\mathrm{ab}}$ & $71.14 \pm 0.04^{\mathrm{g}}$ & $433.99^{\mathrm{h}}$ \\
\hline $\mathrm{K}$ & $4.77 \pm 0.04^{\mathrm{c}}$ & 5.01 & $8.59 \pm 0.04^{\mathrm{c}}$ & $12.74 \pm 0.06^{\mathrm{ef}}$ & $1.187 \pm 0.03^{\mathrm{ab}}$ & $69.42 \pm 0.14^{1}$ & $426.70^{\mathrm{i}}$ \\
\hline $\mathrm{L}$ & $4.89 \pm 0.05^{\mathrm{b}}$ & 5.14 & $8.51 \pm 0.05^{\mathrm{cd}}$ & $12.70 \pm 0.04^{\mathrm{ef}}$ & $1.178 \pm 0.03^{\mathrm{b}}$ & $71.41 \pm 0.03^{\mathrm{f}}$ & $433.98^{\mathrm{h}}$ \\
\hline M & $4.36 \pm 0.07^{\mathrm{f}}$ & 4.56 & $8.91 \pm 0.06^{\mathrm{a}}$ & $11.43 \pm 0.05^{\mathrm{f}}$ & $1.24 \pm 0.03^{\mathrm{a}}$ & $70.08 \pm 0.14^{\mathrm{j}}$ & $418.83^{j}$ \\
\hline $\mathrm{N}$ & $4.71 \pm 0.05^{\mathrm{cd}}$ & 4.94 & $8.85 \pm 0.06^{\mathrm{ab}}$ & $11.40 \pm 0.06^{\mathrm{f}}$ & $1.237 \pm 0.03^{\mathrm{ab}}$ & $71.85 \pm 0.08^{\mathrm{e}}$ & $425.40^{\mathrm{i}}$ \\
\hline $\mathrm{O}$ & $4.84 \pm 0.06^{\mathrm{bc}}$ & 5.09 & $8.76 \pm 0.07^{\mathrm{b}}$ & $11.37 \pm 0.07^{\mathrm{f}}$ & $1.21 \pm 0.03^{\mathrm{ab}}$ & $70.46 \pm 0.06^{\mathrm{i}}$ & $419.21^{\mathrm{j}}$ \\
\hline
\end{tabular}

Values are expressed as mean \pm standard deviation of triplicate testing. Values with the same superscript within the same column indicate no significant difference at $\mathrm{p} \leq 0.05$. $\mathrm{wb}=$ wet weight basis and $\mathrm{db}=$ dry weight basis

biscuits are in agreement with the protein content of the biscuits reported by the other workers.

\subsubsection{Fat}

The fat content was in the range of $11.37-17.88 \%$ (Table 2) in different biscuit samples. The analysis showed that fat content was the highest $(17.88 \%)$ in sample P (control) and was lowest in the sample O $(11.37 \%)$. Significant differences were noticed for the fat content of the biscuit samples at 5\% level of significance. Using of polydextrose to reduce the amount of fat in recipe resulted significantly $(p \leq 0.05)$ on the final fat content of the biscuits and attributed in lowering of maximum $36.41 \%$ fat than control. The differences in fat content among different samples was due to the difference in fat content among the sample's formulation. Lourencetti et al. (2013) found the fat content of inulin fortified reduced-fat biscuits in the range of $4.0-14.2 \%$. Kabirullah et al. (1995), reported that the fat content of biscuits ranges between 5.66 $26.67 \%$, while Seevaratnam et al. (2012) measured 25.8\%. Aggarwal et al. (2016) recorded $21.5 \%$ fat in control biscuit and $14.1 \%$ low-calorie, low - fat biscuits.

\subsubsection{Ash}

The biscuits samples showed the ash content with a range of $1.09-1.24 \%$. It was observed that the ash content of sample $\mathrm{M}$ was the highest (1.24\%) and the sample P (control) gave the lowest ash content (1.09\%) and differed significantly $(p \leq 0.05)$ from all other samples. Ash content of the biscuits increased slightly with the reduction of fat and sugar but decreased with the increasing of the polydextrose and stevia level in the formulation. Kabirullah et al. (1996), analyzed biscuits and found ash content in the range of 1.09 to $2.78 \%$. Lourencetti et al. (2013) found ash content of inulin fortified reduced - fat biscuits in the range $1.54-4.18 \%$. Accordingly, it is concluded that the ash content of developed biscuits was closer to the ranges as mentioned above.

\subsubsection{Total carbohydrate}

The amount of carbohydrate in the developed biscuits was ranged as $68.65-73.72 \%$ (Table 2). Kabirullah et al. (1995) reported that the total carbohydrate content of biscuits in the range of 64.31 $83.45 \%$. Total carbohydrate content was the highest $(73.72 \%)$ in the case of sample B, while sample $\mathrm{P}$ (control) gave the lowest carbohydrate content (68.65\%). The difference in the total carbohydrate content of the sample of biscuits can result from the different protein, fat, ash and moisture content levels.

\subsubsection{Energy (Calorie)}

Table 2 indicates the amount of energy which can be found from consumption of $100 \mathrm{~g}$ biscuits. Amount of protein, carbohydrate and fat content of the processed biscuits affect the total energy content. Reduction of fat and sugar in the initial recipe by replacing with polydextrose and stevia resulted in the considerable 
lowering of the total calorie content. Control sample P had the highest amount of energy as $479.16 \mathrm{cal} / 100 \mathrm{~g}$ biscuit, while the sample $\mathrm{M}$ attributed with the minimum energy content of $418.84 \mathrm{cal} / 100 \mathrm{~g}$. That is, using $3 \mathrm{~g}$ polydextrose in combination with $5 \mathrm{~mL} 2.5 \%$ stevia solution indicated the best formulation as low-calorie biscuits, and resulted in lowering around $12.59 \%$ calorie value. Energy value of the processed low-calorie biscuit with the usage of sugar substitutes and milk - multigrain fat replacer was recorded by Aggarwal et al. (2016) as $485.6 \mathrm{cal} / 100 \mathrm{~g}$ biscuit, which was around $7.59 \%$ lower than the energy value of their processed control biscuits. However, the total energy content of this study was in conformity with the energy values reported by Das et al. (2018) as $465.28-466.82 \mathrm{cal} / 100 \mathrm{~g}$.

\subsection{Physical properties of the biscuits}

The results of physical properties analysis are presented in Table 3. The diameter and thickness of the biscuits decreased significantly $(p \leq 0.05)$ with the decreasing of fat and sugar content, but the addition of the polydextrose and stevia resulted in a slight increase of diameter and thickness. The highest diameter was found in case of sample $\mathrm{P}(3.9 \mathrm{~cm})$ followed by sample $\mathrm{C}$ $(3.85 \mathrm{~cm})$ and sample $\mathrm{F}(3.83 \mathrm{~cm})$. The lowest diameter was represented by $50 \%$ fat and sugar reduction sample, $\mathrm{M}(3.57 \mathrm{~cm})$. Thickness was highest in case of sample $\mathrm{P}$ $(0.7 \mathrm{~cm})$ followed by sample $\mathrm{C}(0.67 \mathrm{~cm})$ and sample B $(0.66 \mathrm{~cm})$. Sample $\mathrm{M}$ showed the lowest thickness value $(0.5 \mathrm{~cm})$. A similar type of result was found by Lourencetti et al. (2013) in the formulations of cookies with $25 \%, 50 \%$ and $75 \%$ reduced - fat by inulin, whereas
Zoulias et al. (2000) reported relatively smaller diameter and thickness in the biscuits with sugar and fat replaced by inulin and maltodextrin than the standard formulation. Results of this study for diameter and thickness were more or less similar to that reported by Hussain and Kaul (2018) and almost complied with Das et al. (2018) as the results were in the range of the values reported by these authors. This reduction in dimension can be correlated with the elastic recoil capability provided by carbohydrate - based fat replacer. Spread ratio is considered as one of the most important parameters of biscuit consistency, significantly $(p \leq 0.05)$ influenced by the reduction of fat and sugar. Spread ratio was increased with the reduction of fat and sugar, while in addition of polydextrose and stevia, there was a slight decrease in spread ratio. Spread ratio was the highest (7.1) in case of sample $\mathrm{M}$ followed by the sample $\mathrm{N}$ (7.03) and sample $\mathrm{O}$ (7.0), while the lowest value (5.58) was given by sample P (control). Spread ratio recorded by Das et al. (2018) as 4.66 - 7.24 for composite biscuits complied with the values of this study, whilst Radhika et al. (2019) reported even higher spread ratio of 8.84 - 10.22. Probably polydextrose and stevia effects resulted in increasing of spread ratio. However, the difference in the size of mold and baking conditions may be responsible for the difference of spread ratio, thickness and diameter values with that reported by other authors.

Mass of the biscuit samples was decreased with the reduction of fat and sugar, while further increased with the increasing of the polydextrose level since fat, sugar and polydextrose has higher density compared to wheat flour. Mass was highest in case of the sample C (4.2 g),

Table 3. Physical properties of the developed biscuits

\begin{tabular}{|c|c|c|c|c|c|c|c|}
\hline Sample & Diameter $(\mathrm{cm})$ & Thickness $(\mathrm{cm})$ & Spread ratio & Mass (g) & Volume (cc) & Density (g/cc) & Compression force (kgf) \\
\hline $\mathrm{P}$ & $3.90 \pm 0.05^{\mathrm{ab}}$ & $0.70 \pm 0.021^{\mathrm{bc}}$ & $5.58 \pm 0.183^{\mathrm{cd}}$ & $4.11 \pm 0.031^{\mathrm{bc}}$ & $8.34 \pm 0.335^{\mathrm{bc}}$ & $0.49 \pm 0.03^{\text {cd }}$ & $9.38 \pm 0.03^{\mathrm{k}}$ \\
\hline A & $3.68 \pm 0.03^{\mathrm{c}}$ & $0.62 \pm 0.02^{\mathrm{bc}}$ & $5.95 \pm 0.233^{\mathrm{cd}}$ & $4.04 \pm 0.036^{\mathrm{c}}$ & $6.60 \pm 0.134^{\text {cd }}$ & $0.61 \pm 0.017^{\mathrm{c}}$ & $10.67 \pm 0.02^{\mathrm{i}}$ \\
\hline B & $3.82 \pm 0.03^{\mathrm{ab}}$ & $0.66 \pm 0.02^{\mathrm{b}}$ & $5.82 \pm 0.20^{\mathrm{d}}$ & $4.12 \pm 0.04^{\mathrm{b}}$ & $7.51 \pm 0.23^{\mathrm{b}}$ & $0.55 \pm 0.02^{\mathrm{d}}$ & $10.47 \pm 0.02^{\mathrm{ij}}$ \\
\hline $\mathrm{C}$ & $3.85 \pm 0.05^{\mathrm{a}}$ & $0.67 \pm 0.02^{\mathrm{a}}$ & $5.74 \pm 0.20^{\mathrm{d}}$ & $4.20 \pm 0.05^{\mathrm{a}}$ & $7.98 \pm 0.22^{\mathrm{a}}$ & $0.53 \pm 0.01^{\mathrm{d}}$ & $10.33 \pm 0.02^{\mathrm{j}}$ \\
\hline $\mathrm{D}$ & $3.67 \pm 0.03^{\mathrm{cd}}$ & $0.60 \pm 0.02^{\text {cd }}$ & $6.12 \pm 0.21^{\mathrm{cd}}$ & $3.92 \pm 0.04^{\mathrm{de}}$ & $6.34 \pm 0.23^{\mathrm{d}}$ & $0.62 \pm 0.03^{b c}$ & $12.12 \pm 0.02^{\mathrm{g}}$ \\
\hline $\mathrm{E}$ & $3.80 \pm 0.05^{\mathrm{ab}}$ & $0.63 \pm 0.02^{\mathrm{bc}}$ & $6.0 \pm 0.14^{\mathrm{cd}}$ & $4.04 \pm 0.05^{\mathrm{c}}$ & $7.18 \pm 0.29^{\mathrm{bc}}$ & $0.56 \pm 0.02^{\mathrm{cd}}$ & $11.98 \pm 0.01^{\mathrm{gh}}$ \\
\hline $\mathrm{F}$ & $3.83 \pm 0.03^{\mathrm{ab}}$ & $0.65 \pm 0.03^{\mathrm{ab}}$ & $5.88 \pm 0.25^{\mathrm{d}}$ & $4.12 \pm 0.04^{\mathrm{b}}$ & $7.48 \pm 0.19^{\mathrm{ab}}$ & $0.53 \pm 0.02^{\mathrm{d}}$ & $11.79 \pm 0.18^{\mathrm{h}}$ \\
\hline G & $3.63 \pm 0.03^{\mathrm{cd}}$ & $0.57 \pm 0.03^{\mathrm{d}}$ & $6.35 \pm 0.28^{\mathrm{bc}}$ & $3.81 \pm 0.04^{\mathrm{e}}$ & $5.94 \pm 0.29^{\mathrm{e}}$ & $0.64 \pm 0.03^{\mathrm{bc}}$ & $13.63 \pm 0.02^{\mathrm{e}}$ \\
\hline $\mathrm{H}$ & $3.77 \pm 0.04^{\mathrm{bc}}$ & $0.62 \pm 0.01^{\mathrm{bc}}$ & $6.08 \pm 0.11^{\mathrm{cd}}$ & $3.93 \pm 0.04^{\mathrm{d}}$ & $6.91 \pm 0.15^{\mathrm{c}}$ & $0.57 \pm 0.01^{\mathrm{cd}}$ & $13.49 \pm 0.02^{\mathrm{ef}}$ \\
\hline I & $3.78 \pm 0.03^{\mathrm{b}}$ & $0.61 \pm 0.01^{\mathrm{c}}$ & $6.20 \pm 0.07^{\mathrm{c}}$ & $4.04 \pm 0.05^{\mathrm{c}}$ & $6.86 \pm 0.21^{\mathrm{cd}}$ & $0.59 \pm 0.01^{\mathrm{cd}}$ & $13.33 \pm 0.02^{\mathrm{f}}$ \\
\hline $\mathrm{J}$ & $3.62 \pm 0.03^{\mathrm{cd}}$ & $0.54 \pm 0.02^{\mathrm{de}}$ & $6.66 \pm 0.20^{\mathrm{b}}$ & $3.73 \pm 0.04^{\mathrm{f}}$ & $5.58 \pm 0.16^{\mathrm{ef}}$ & $0.67 \pm 0.03^{\mathrm{b}}$ & $14.88 \pm 0.01^{\mathrm{c}}$ \\
\hline K & $3.67 \pm 0.02^{\mathrm{cd}}$ & $0.55 \pm 0.02^{\mathrm{de}}$ & $6.67 \pm 0.25^{\mathrm{ab}}$ & $3.78 \pm 0.04^{\mathrm{ef}}$ & $5.81 \pm 0.23^{\mathrm{ef}}$ & $0.65 \pm 0.03^{b c}$ & $14.73 \pm 0.01^{\mathrm{cd}}$ \\
\hline $\mathrm{L}$ & $3.68 \pm 0.02^{\mathrm{c}}$ & $0.56 \pm 0.03^{\mathrm{de}}$ & $6.62 \pm 0.25^{\mathrm{c}}$ & $3.88 \pm 0.03^{\mathrm{de}}$ & $5.93 \pm 0.35^{\text {ef }}$ & $0.66 \pm 0.04^{\mathrm{bc}}$ & $14.56 \pm 0.03^{\mathrm{d}}$ \\
\hline $\mathrm{M}$ & $3.57 \pm 0.04^{\mathrm{d}}$ & $0.50 \pm 0.03^{\mathrm{e}}$ & $7.10 \pm 0.40^{\mathrm{a}}$ & $3.63 \pm 0.04^{\mathrm{g}}$ & $5.03 \pm 0.19^{f}$ & $0.72 \pm 0.03^{\mathrm{ab}}$ & $16.44 \pm 0.02^{\mathrm{a}}$ \\
\hline $\mathrm{N}$ & $3.58 \pm 0.03^{\mathrm{d}}$ & $0.51 \pm 0.01^{\mathrm{e}}$ & $7.03 \pm 0.09^{\mathrm{ab}}$ & $3.71 \pm 0.02^{\mathrm{fg}}$ & $5.14 \pm 0.18^{\mathrm{f}}$ & $0.72 \pm 0.03^{\mathrm{ab}}$ & $16.29 \pm 0.01^{\mathrm{ab}}$ \\
\hline $\mathrm{O}$ & $3.58 \pm 0.06^{\mathrm{d}}$ & $0.51 \pm 0.02^{\mathrm{e}}$ & $7.00 \pm 0.30^{\mathrm{ab}}$ & $3.79 \pm 0.05^{\mathrm{ef}}$ & $5.14 \pm 0.26^{\mathrm{f}}$ & $0.74 \pm 0.05^{\mathrm{a}}$ & $16.12 \pm 0.02^{\mathrm{b}}$ \\
\hline
\end{tabular}

Values are expressed as mean \pm standard deviation of triplicate testing. Values with the same superscript within the same column indicate no significant difference at $\mathrm{p} \leq 0.05$. 
followed by sample B and F (4.12 g). The lowest value was found in the case of sample M $(3.63 \mathrm{~g})$. The highest volume was in the case of sample $\mathrm{P}(8.34 \mathrm{cc})$ followed by sample $\mathrm{C}(7.98 \mathrm{cc})$ and sample $\mathrm{B}(7.51 \mathrm{cc})$. The lowest volume was represented by the sample M (5.03 cc). The volume of the biscuits decreased with the decreasing of fat and sugar, but the addition of the polydextrose resulted in a further slight increase in volume.

Density is the function of mass and volume and was increased with the reduction of fat and sugar, while in addition of polydextrose density decreased slightly. The highest value was found in case of sample $\mathrm{O}(0.74 \mathrm{~g} / \mathrm{cc})$ followed by sample $\mathrm{M}$ and $\mathrm{N}(0.72 \mathrm{~g} / \mathrm{cc})$. The lowest value was shown by sample $\mathrm{P}(0.49 \mathrm{~g} / \mathrm{cc})$. The values of density were in conformity with the reported values of Das et al. (2018).

The highest compression value is associated with a higher percentage of fat and sugar replacement since fat shorts the gluten activity. The compressive value was found in the range $9.38-16.44 \mathrm{kgf}$ where sample $\mathrm{M}$ and sample $\mathrm{P}$ shows the highest (16.44 $\mathrm{kgf}$ ) and the lowest (9.38 kgf) value respectively. Lourencetti et al. (2013) found the compressive force of the inulin fortified reduced - fat biscuits in the range 12.58 - $18.55(\mathrm{kgf})$. The values of compressive strength also complied with Forker et al. (2012). Significant $(p \leq 0.05)$ increasing of compressive values represent the effectiveness of polydextrose and stevia to increase the toughness of bakery products.

\subsection{Sensory evaluation}

The scores obtained from sensory analysis for control, and polydextrose and stevia supplemented lowcalorie biscuits are presented in Table 4. It is seen that there were significant differences in color, flavor, texture and overall acceptability preference among the samples at $5 \%$ level of significance. Concerning color preference, the score of biscuits was decreasing with the reduction of fat and sugar, while in addition of polydextrose and stevia resulted further enhance of color scores. The highest color score was obtained by the sample P (8.20) and the lowest score was found for the sample M (5.20). Among the biscuits with low-calorie formulation, sample $\mathrm{C}$ which was formulated by reducing $10 \%$ fat and sugar, and by using $9 \mathrm{~g}$ polydextrose and $1 \mathrm{~mL} 2.5 \%$ stevia solution secured the highest score of 8.07, also it was equally acceptable to control sample P. In case of flavor, the control biscuit sample $\mathrm{P}$ showed the highest score (8.47) while sample $M$ showed the lowest score (5.47). The flavor of the biscuit was decreased with the decrease in fat and sugar. At the same time, in addition to polydextrose and stevia further improves the flavor of the biscuits. Texture, an important quality feature of biscuit which directly affects the acceptance and sales. The composition and texture of the biscuits are substantially directly related. The texture of the prepared biscuits was degrading due to the reduction of the fat and sugar quantity in the formulation, which subsequently resulted in decreasing the scores provided by the taste panelist. But, with the addition of polydextrose and

Table 4. Sensory scores of the developed biscuits

\begin{tabular}{|c|c|c|c|c|}
\hline \multirow{2}{*}{ Sample } & \multicolumn{4}{|c|}{ Sensory Parameters } \\
\hline & Color & Flavor & Texture & Overall Acceptability \\
\hline $\mathrm{P}$ & $8.20 \pm 0.68^{\mathrm{a}}$ & $8.47 \pm 0.52^{\mathrm{a}}$ & $8.07 \pm 0.88^{\mathrm{ab}}$ & $8.13 \pm 0.64^{\mathrm{a}}$ \\
\hline A & $7.40 \pm 0.63^{b c}$ & $7.60 \pm 0.51^{\mathrm{c}}$ & $7.07 \pm 0.78^{b c}$ & $7.20 \pm 0.68^{\mathrm{bc}}$ \\
\hline B & $7.87 \pm 0.83^{\mathrm{ab}}$ & $7.73 \pm 0.80^{\mathrm{b}}$ & $7.47 \pm 0.83^{\mathrm{ab}}$ & $7.47 \pm 0.64^{\mathrm{bc}}$ \\
\hline $\mathrm{C}$ & $8.07 \pm 0.70^{\mathrm{ab}}$ & $8.00 \pm 0.76^{\mathrm{ab}}$ & $8.13 \pm 0.83^{\mathrm{a}}$ & $8.00 \pm 0.76^{\mathrm{ab}}$ \\
\hline $\mathrm{D}$ & $7.00 \pm 0.76^{\mathrm{cd}}$ & $6.93 \pm 0.80^{\mathrm{cd}}$ & $6.87 \pm 0.83^{b c}$ & $6.93 \pm 0.80^{\mathrm{c}}$ \\
\hline $\mathrm{E}$ & $7.20 \pm 0.78^{\mathrm{bc}}$ & $7.13 \pm 0.74^{\mathrm{c}}$ & $7.27 \pm 0.80^{\mathrm{b}}$ & $7.13 \pm 0.74^{\mathrm{bc}}$ \\
\hline $\mathrm{F}$ & $7.67 \pm 0.62^{b}$ & $7.40 \pm 0.74^{\mathrm{bc}}$ & $7.80 \pm 0.78^{\mathrm{ab}}$ & $7.53 \pm 0.64^{b}$ \\
\hline G & $6.33 \pm 0.72^{\mathrm{d}}$ & $6.40 \pm 0.63^{\mathrm{de}}$ & $6.67 \pm 0.70^{\mathrm{bc}}$ & $6.47 \pm 0.52^{\text {cd }}$ \\
\hline $\mathrm{H}$ & $6.87 \pm 0.83^{\mathrm{cd}}$ & $6.67 \pm 0.72^{\mathrm{cd}}$ & $6.93 \pm 0.85^{\mathrm{bc}}$ & $6.87 \pm 0.74^{\mathrm{cd}}$ \\
\hline I & $7.13 \pm 0.92^{\mathrm{c}}$ & $6.87 \pm 0.74^{\mathrm{cd}}$ & $7.07 \pm 0.88^{\mathrm{bc}}$ & $7.20 \pm 0.78^{\mathrm{bc}}$ \\
\hline $\mathrm{J}$ & $5.67 \pm 0.82^{\mathrm{ef}}$ & $5.73 \pm 0.79^{\mathrm{e}}$ & $6.13 \pm 0.88^{\mathrm{cd}}$ & $5.80 \pm 0.78^{\mathrm{de}}$ \\
\hline K & $5.93 \pm 0.70^{\mathrm{de}}$ & $6.13 \pm 0.74^{\mathrm{de}}$ & $6.47 \pm 0.79^{\mathrm{c}}$ & $6.27 \pm 0.70^{\mathrm{d}}$ \\
\hline $\mathrm{L}$ & $6.20 \pm 0.78^{\mathrm{de}}$ & $6.47 \pm 0.64^{\mathrm{d}}$ & $6.73 \pm 0.93^{b c}$ & $6.47 \pm 0.52^{\mathrm{cd}}$ \\
\hline M & $5.20 \pm 0.78^{\mathrm{f}}$ & $5.47 \pm 0.52^{\mathrm{e}}$ & $5.33 \pm 0.62^{\mathrm{d}}$ & $5.40 \pm 0.51^{\mathrm{e}}$ \\
\hline $\mathrm{N}$ & $5.47 \pm 0.64^{\mathrm{ef}}$ & $5.67 \pm 0.72^{\mathrm{e}}$ & $5.87 \pm 0.83^{\mathrm{cd}}$ & $5.80 \pm 0.56^{\mathrm{de}}$ \\
\hline $\mathrm{O}$ & $5.80 \pm 0.68^{\mathrm{e}}$ & $6.00 \pm 0.66^{\mathrm{de}}$ & $6.20 \pm 0.88^{\mathrm{cd}}$ & $6.13 \pm 0.83^{\mathrm{de}}$ \\
\hline
\end{tabular}

Values are expressed as mean \pm standard deviation of triplicate testing. Values with the same superscript within the same column indicate no significant difference at $\mathrm{p} \leq 0.05$. 
stevia level resulted in improvement of the biscuit texture as found as for color and flavor also. The highest and the lowest scores were secured by the control sample $P$ (8.07) and the sample $M$ (5.33), respectively. The overall acceptability of the biscuits was justified on the basis of the scores of the color, flavor and texture where the control sample $\mathrm{P}$ and the sample $\mathrm{M}$ showed the highest (8.13) and the lowest (5.4) scores respectively. Sample C having $9 \mathrm{~g}$ polydextrose and $1 \mathrm{~mL} 2.5 \%$ stevia solution as formulated for $10 \%$ fat and sugar reduction was the best among the developed biscuits rather than control. However, all of the biscuits samples got a score higher than 5 (neither like nor dislike). A more or less similar type of result was also noted by Lourencetti et al. (2013), where biscuits with 50\% reduced - fat supplemented with inulin obtained highest preference to the panelist among low-calorie biscuits. Aggarwal et al. (2016) also noticed that the sensory values decrease in the low-calorie biscuits. Based on sensory properties, it can be said that $10 \%$ fat and sugar reduction from the recipe of the biscuits would be equally acceptable to the panelists, though up to $50 \%$ is acceptable as sensory scores were above the preferable value.

\section{Conclusion}

From the study, it is apparent that polydextrose and stevia can be considered as potential and effective replacer of fat and sugar respectively in biscuit preparation. Significant changes in physical and chemical properties were noticed due to the reduction of fat and sugar amount in the initial formulation. In addition, polydextrose containing biscuits were more preferable to the taste panelists, also showed better physical and chemical characteristics. However, further research is recommended in this area, specifically on the development and optimization of low fat and low sugar processed food with more combination of polydextrose and stevia.

\section{Conflict of interest}

The authors declare no conflict of interest.

\section{Acknowledgement}

The authors feel proud to acknowledge National Science and Technology (NST) fellowship under the Ministry of Science and Technology (MoST), Bangladesh for providing the fund to carry out this research.

\section{References}

AACC. (2000). Approved Methods of the American Association of Cereal Chemists. Methods 08-01, 30
$-25,44-15$ A , 46-10, 54-10, 54-21. $10^{\text {th }}$ ed. St. Paul, MN, USA: AACC

Aggarwal, D., Sabikhi, L. and Kumar, M.H.S. (2016). Formulation of reduced - calorie biscuits using artificial sweeteners and fat replacer with dairymultigrain approach. NFS Journal, 2(2), 1 - 7. https://doi.org/10.1016/j.nfs.2015.10.001

Akoh, C.C. (1995). Lipid - based fat - substitutes. Food Science and Nutrition, 35(5), 405 - 430. https:// doi.org/10.1080/10408399509527707

Akoh, C.C. (1998). Fat replacers. Food Technology, 52 (3), $47-53$.

Amerine, M.A., Pangborn, R.M. and Roessler, E.B. (1965). Principles of Sensory Evaluation of Food. 1st ed. London, UK: Academic Press. https:// doi.org/10.1016/B978-1-4832-0018-7.50005 - 2

AOAC. (2012). Official Methods of Analysis of Analytical Chemists. $19^{\text {th }}$ ed. Washington DC, USA: AOAC.

Begum, S., Das, P.C. and Karmoker, P. (2018). Processing of mixed fruit juice from mango, orange and pineapple. Fundamental and Applied Agriculture, 3(2), 440-445. https://doi.org/10.5455/ faa.289995

Bell, S.J. and Sears, B. (2003). Low - glycemic - load diets: impact on obesity and chronic diseases. Critical Reviews in Food Science and Nutrition, 43 (4), 357- $377 . \quad \mathrm{https} / /$ doi.org/10.1080/10408690390826554

Bonovas, S., Filioussi, K. and Tsantes, A. (2004). Diabetes mellitus and risk of prostate cancer: a meta - analysis. Diabetologia, 47(6), 1071 - 1078. https:// doi.org/10.1007/s00125-004-1415-6

Das, P.C., Khan J., Rahman M.S., Majumder S. and Islam M.N. (2019). Comparison of the physic chemical and functional properties of mango kernel flour with wheat flour and development of mango kernel flour based composite cakes. NFS Journal, 17, 1-7. https://doi.org/10.1016/j.nfs.2019.10.001

Das, P.C., Rana, M.S., Saifullah, M. and Islam, M.N. (2018). Development of composite biscuits supplementing with potato or corn flour. Fundamental and Applied Agriculture, 3(2), 453459. https://doi.org/10.5455/faa.292438

Ding, E.L. and Malik, V.S. (2008). Convergence of obesity and high glycemic diet on compounding diabetes and cardiovascular risks in modernizing China: An emerging public health dilemma. Globalization and Health, 4(4), 1 - 8. https:// doi.org/10.1186/1744-8603-4-4

Eyre, H., Kahn, R., Robertson, R.M., Clark, N.G., Doyle, C., Hong, Y., Gansler, T., Glynn, T., Smith, R.A., 
Taubert, K. and Thun, M.J. (2004). Preventing cancer, cardiovascular disease and diabetes: a common agenda for the American Cancer Society, the American Diabetes Association, and the American Heart Association. Circulation, 109(25), $3244 \quad-3255 . \quad 3$ https:// doi.org/10.1161/01.CIR.0000133321.00456.00

Forker, A., Zahn, S. and Rohm, H. (2012). A combination of fat replacers enables the production of fat - reduced short dough biscuits with high sensory quality. Food Bioprocess Technology, 5(6), 2497-2505. https://doi.org/10.1007/s11947-0110536-4

Franceschi, S., Dal Maso, L. and Augustin, L. (2001). Dietary Glycemic Load and Colorectal Cancer Risk. Annals of Oncology, 12(2), 173 - 178. https:// doi.org/10.1023/A:1008304128577

Gallagher, E., O'Brien, C.M., Scannell, A.G.M. and Arendt, E.K. (2003). Evaluation of sugar replacers in short dough biscuit production. Journal of Food Engineering, 56(2 - 3), 261-263. https:// doi.org/10.1016/S0260-8774(02)00267-4

Giese, J. (1996). Fats, oils, and fat replacers. Food Technology, 50(4), 78 - 83.

Gomez, K.A. and Gomez, A.A. (1984). Statistical Procedures for Agricultural Research. $2^{\text {nd }}$ ed. New York, USA: John Wiley and Sons.

Grah, A.M.B., Beda, M.Y., Aubin, P.D., Niaba, K.P.V. and Gnakri, D. (2014). Manufacture of biscuit from the flour of wheat and lentil seeds as a food supplement. European Journal of Food Science and Technology, 2(2), 23-32.

Hussain, A. and Kaul, R. (2018). Formulation and Characterization of Buckwheat - Barley Supplemented Multigrain Biscuits. Current. Research in Nutrition and Food Science Journal, 6 (3), 873 - 881. https://doi.org/10.12944/ CRNFSJ.6.3.30

Hussein, A.M.S., El - Azeem, A.S.A., Hegazy, A.M., Abeer Afifi, A. and Ragab, G.H. (2011). Physiochemical, sensory and nutritional properties of corn - fenugreek flour composite biscuits. Australian Journal of Basic and Applied Sciences, 5(4), 84 - 95.

Kabirullah, M., Rukonuddin, A., Khan, S.A., Mosharef, H., Mojibur, R.A.K.M., Azizul, M.I.K. and Moazzam, M.H. (1995). Analysis of Nutrients of Bangldeshi Processed Foods. Part - 1: Different types of biscuits. Bangladesh Journal of Scientific and Industrial Research, 30(1), 121.

Kabirullah, M., Rukonuddin, A., Khan, S.A., Tasnim, A., Mojibur, R.A.K.M., Islam, K.M.A. and Moazzam, M.H. (1996). Analysis of Nutrients of
Bangladeshi Processed Foods. Different types of biscuits. Bangladesh Journal of Scientific and Industrial Research, 31(3), 89 - 101.

Lim, J., Inglet, E.G. and Lee, S. (2010). Response to consumer demand for reduced fat foods: multifunctional fat replacers. Japan Journal of Food Engineering, 11(4), 147-152. https:// doi.org/10.11301/jsfe.11.147

Lin, S.D., Lee, C.C., Mau, J.L., Lin, L.Y. and Chiou, SY. (2010). Effect of erythritol on quality characteristics of reduced - calorie Danish cookies. Journal of Food Quality, 33(1), 14 - 26. https://doi.org/10.1111/ j.1745-4557.2010.00307.x

Lindsay, R.C. (1996). Food Additives. In Food Chemistry, Fennema, (Eds). Food chemistry, p. 767 823. New York, USA: John Wiley and Sons.

Lourencetti, R.E., Benossi, L., Marques, D.R., Joia, B.M. and Monteiro, A.R.G. (2013). Development of Biscuit Type Cookie with Partial Replacement of Fat by Inulin. International Journal of Nutrition and Food Sciences, 2(5), 261 - 265. https:// doi.org/10.11648/j.ijnfs.20130205.18

Mariotti, M. and Alamprese, C. (2012). About the use of different sweeteners in baked goods. Influence on the mechanical and rheological properties of the doughs. LWT - Food Science and Technology, 48(1), 9-15. https://doi.org/10.1016/j.lwt.2012.03.001

Marufa, M.A., Das, P.C. and Iqbal, A. (2019). Utilization of Jamun seed powder in composite cake formulation. Journal of Bangladesh Agricultural University, 17(4), 599-605. https://doi.org/10.3329/ jbau.v17i4.44632

Masoodi, L. and Bashir, V.A.K. (2012). Fortification of Biscuit with Flaxseed, Biscuit Production and Quality Evaluation. Journal of Environmental Science, Toxicology and Food Technology, 26(1), 6 9. https://doi.org/10.9790/2402 - 0150609

Michaud, D.S., Liu, S. and Giovannucci, E. (2002). Dietary Sugar, Glycemic Load, and Pancreatic Cancer Risk in a Prospective Study. Journal of the National Cancer Institute, 94(17), 1293 - 1300. https://doi.org/10.1093/jnci/94.17.1293

Mitchell, H.L. (1996). The role of bulking agent polydextrose in fat replacement. In Roller, S. and Jones, S.A. (Eds.). Handbook of Fat Replacers, p. 235-248. Boca Raton, Florida: CRC Press. https:// doi.org/10.1201/9781420048971.ch11

Nonaka, H.H. (1997). Plant carbohydrate derived products as fat replacers and calorie reducers. Cereal Foods World, 42(5), 377 - 378.

Okoye, Z.S.C. (Ed.). (1992). Chemical and Biochemical Indices of Food Quality. In Biochemical Aspects of 
Nutrition, p. 137. New Delhi, India: Prentice - Hall of India Private Ltd.

Oliveira, D.M., Marques, D.R., Kwiatkowski, A., Monteiro, A.R.G. and Clemente, E. (2013). Sensory analysis and chemical characterization of cereal enriched with grape peel and seed flour. Acta Scientiarum Technology, 35, 427 - 432. https:// doi.org/10.4025/actascitechnol.v35i3.13176

Pearson, D. (1976). The Chemical Analysis of Food. $7^{\text {th }}$ ed., p. 72 - 89. Edinburgh: Churchill Livingstone.

Radhika, Virk, A., Kaur, M., Thakur, P. Chauhan, D., Rizvi, Q.U.E.H., Jan, S. and Kumar, K. (2019). Development and Nutritional Evaluation of Multigrain Gluten Free Cookies and Pasta Products. Current. Research in Nutrition and Food Science Journal, 7(3), 842 - 853. https://doi.org/10.12944/ CRNFSJ.7.3.23

Ranganna, S. (2005). Hand Book of Analysis of Quality Control for Fruit and Vegetable Products. $2^{\text {nd }}$ ed. New Delhi, India: Tata McGraw Hill Publications Company Limited.

Romieu, I., Lazcano - Ponce, E. and Sanchez Zamorano, L.M. (2004). Carbohydrates and the Risk of Breast Cancer among Mexican Women. Cancer Epidemiology and Biomarkers Preview, 13(8), 1283 - 1289.

Sarker, A., Islam, M. and Shaheb, M. (2013). Kinetics of dehydration of potato and development of baked product based on dehydrated potato. Journal of the Bangladesh Agricultural University, 10(2), 303 312. https://doi.org/10.3329/jbau.v10i2.14923

Seevaratnam, V.P.B., Premalatha, M.R., Sundaram, S.P. and Arumugam, T. (2012). Studies on the preparation of biscuits incorporated with potato flour. World Journal of Dairy and Food Science, 7 (1), 79-84.

Viana, F.R., Silva, V.D.M., Carvalho, M., Das, G., Oliveira, A.L. and Silvestre, M.P.C. (2008). Efeito da substituição parcial da gordura pela globina e plasma bovinos em patê de presunto. Acta Scientiarum. Biological Sciences, 25(1), 233 - 240.

Zoulias, E.I., Oreopoulou, V. and Tzia, C. (2000). Effect of fat mimetics on physical, textural and sensory properties of cookies. International Journal of Food Properties, 3(3), $385 \quad$ - $397 . \quad \mathrm{https}: / /$ doi.org/10.1080/10942910009524643 